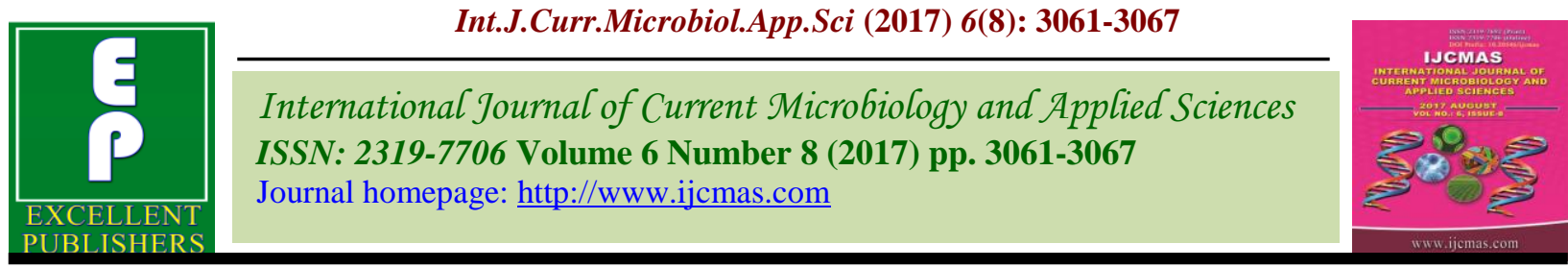

Original Research Article

https://doi.org/10.20546/ijcmas.2017.608.366

\title{
Yield and Yield Attributes Influenced by Different Planting Methods and Nitrogen Treatments
}

\author{
S. Praneeth ${ }^{1 *}$, D. Vishnu Vardhan Reddy ${ }^{1}$, R. Mahender Kumar², \\ P.C. Latha ${ }^{3}$, T. Ramesh $^{1}$ and Raguveer Rao ${ }^{1}$ \\ ${ }^{1}$ Department of Crop Physiology, College of Agriculture, PJTSAU, Hyderabad, Telangana, India \\ ${ }^{2}$ Deptartment of Agronomy, ${ }^{3}$ Deptartment of Soil Science, IIRR, Hyderabad, Telangana, India \\ *Corresponding author
}

\begin{tabular}{|c|c|}
\hline & A B S T R A C T \\
\hline $\begin{array}{l}\text { Yield attributes, } \\
\text { Planting methods } \\
\text { and Nitrogen } \\
\text { treatments. }\end{array}$ & \multirow{3}{*}{$\begin{array}{l}\text { This paper examines the yield and yield attributes under different planting } \\
\text { methods and nitrogen treatments. Yield attributes like panicle length, filled } \\
\text { grain and unfilled grain percentage, test weight, grain yield, straw yield and } \\
\text { harvest index performed well under system of rice intensification compared } \\
\text { to normal transplantation. Among the nitrogen management practices } 75 \% \\
\text { inorganic+ } 25 \% \text { organic }\left(\mathrm{N}_{5}\right) \text { treatment showed better performance } \\
\text { compared to } 100 \% \text { inorganic }\left(\mathrm{N}_{6}\right), 100 \% \text { organic }\left(\mathrm{N}_{2}\right) \text {, } 50 \% \text { organic }+50 \% \\
\text { inorganic }\left(\mathrm{N}_{4}\right), 75 \% \text { organic }+25 \% \text { inorganic }\left(\mathrm{N}_{3}\right) \text { and control }\left(\mathrm{N}_{1}\right) \text {. Grain } \\
\text { yield was increased significantly by } 18.3 \% \text { under SRI over NTP. Among } \\
\text { nitrogen treatments } \mathrm{N}_{5} \text { enhanced } 37.8 \% \text { yield over } \mathrm{N}_{1} \text {. }\end{array}$} \\
\hline Article Info & \\
\hline $\begin{array}{l}\text { Accepted: } \\
\text { 23 June } 2017 \\
\text { Available Online: } \\
\text { 10 August } 2017\end{array}$ & \\
\hline
\end{tabular}

\section{Introduction}

Rice is the most important staple food crops in the world. India has the largest area (42.27 $\mathrm{m}$ ha) and it is the second largest producer $(105.24 \mathrm{~m} \mathrm{t})$ of rice next to China $(144 \mathrm{~m} \mathrm{t})$. Rice is a heavy water consumer but water for rice production is becoming scarce and expensive due to the increased demand for water from the ever growing population (Choudhary et al., 2013). Future predications on water scarcity limiting agricultural production have estimated that by 2025 , about $15-20 \mathrm{~m}$ ha of Asia's irrigated rice fields will suffer from water shortage in the dry season especially since flood irrigated rice uses more than $45 \%$ of $90 \%$ of total freshwater used for agricultural purposes (Tuong and Bouman,
2003). Traditional planting has been the most important and common method of crop establishment practice under irrigated lowland rice ecosystems in tropical Asia. In irrigated lowland rice which not only consumes more water but also causes wastage of water resulting in degradation of land. In recent years to tackle this problem, many methods of cultivation have been developed and one among them is System of Rice Intensification (SRI). The SRI was developed in Madagascar during early 1980s (Laulanie, 1993) is a system approach to increase rice productivity with less external and inexpensive inputs. SRI method of cultivation is slowly gaining momentum all over the world including India. 
Among nutrients, nitrogen is the most important limiting element in rice growth (Jayanthi et al., 2007). Organic manures have the capacity to fulfil nutrient demand of crops adequately and promote the activity of macro and micro flora in the soil. Organic nutrition to rice is assuming significance in the context of an increasing concern about sustaining soil health with increasing use of inorganic nutrition on one hand and expected shortage in nitrogen fertilizer for rice cultivation on the other hand. Keeping these points how rice plants performed better under SRI method with different nitrogen treatments.

\section{Materials and Methods}

The present investigation entitled "Yield and yield attributes influenced by different planting methods and nitrogen treatments" was conducted during the rabi for two annual season of 2015 and 2016 at Indian Institute of Rice Research (IIRR) formerly Directorate of Rice Research (DRR) farm, ICRISAT, Patancheruv, Hyderabad. The experiment was laid out in a split plot design with main plots consisting of two methods of cultivation i.e., System of rice intensification (SRI) and normal traditional cultivation (NTP) and sub plots comprising of six nitrogen management practices like Control $\left(\mathrm{N}_{1}\right), 100 \%$ organic $\left(\mathrm{N}_{2}\right), 75 \%$ organic $+25 \%$ inorganic $\left(\mathrm{N}_{3}\right), 50$ $\%$ organic $+50 \%$ inorganic $\left(\mathrm{N}_{4}\right), 25 \%$ organic $+75 \%$ inorganic $\left(\mathrm{N}_{5}\right), 100 \%$ inorganic $\left(\mathrm{N}_{6}\right)$.

The treatments were replicated three times. Ten panicles were selected randomly from the net plot area for recording the panicle length. It was measured from the base of the primary rachis to top most spikelet and average length was expressed in $\mathrm{cm}$. After counting filled and unfilled grains present on panicle the filled grain percentage and spikelet sterility percentage was calculated with help of following formula (Filled grain percentage=
Number of filled grains/Total number of graims x 100 and Spikelet sterility percentage $=$ Number of unfilled grains /Total number of grains $x$ 100). Thousand grains were counted from the grains obtained from five randomly selected hills and the weight was recorded as test weight in grams (g). Plants in the net plot area were harvested separately in each plot threshed and grains were separated, dried under sun and the grain yield per plot was recorded after cleaning. From this yield per plot was computed and expressed as $\mathrm{kg}^{-} \mathrm{ha}^{-}$ ${ }^{1}$.After threshing the grain, the remaining straw was dried under sun and yield per plot was recorded and the yield per hectare was computed and expressed in $\mathrm{kg} \mathrm{ha}^{-1}$.

\section{Results and Discussion}

Significantly higher panicle length was noticed in system of rice intensification (6.2, 5.2 and $5.7 \%$ in 2015, 2016 and pooled means, respectively) over NTP. The SRI was found to produce larger individual plants and which resulted in better light distribution, larger total leaf area, higher plant dry weight and longer panicles (Table 1). Several researchers (Mohanty et al., 2014) also reported similar results. In nitrogen treatments, higher panicle length was (24.1, 24.7 and $24.4 \mathrm{~cm}$ in 2015, 2016 and pooled means, respectively) obtained with $25 \%$ organic $+75 \%$ inorganic $\left(\mathrm{N}_{5}\right)$ nitrogen treatment over other nitrogen treatments. $\mathrm{N}_{6}$, $\mathrm{N}_{2}, \mathrm{~N}_{4}, \mathrm{~N}_{3}$ treatments were statistically on par with each other but significantly superior than control $\left(\mathrm{N}_{1}\right)$ during both the years of study. The lowest panicle length was found in control $\left(\mathrm{N}_{1}\right)(22.1,22.2$ and $22.1 \mathrm{~cm}$ in 2015, 2016 and pooled means, respectively). Application of organic and inorganic nitrogen supply as in $25 \%$ organic $+75 \%$ inorganic $\left(\mathrm{N}_{5}\right)$ nitrogen treatment results in continuous supply of nutrients throughout crop growth period (Damodaran et al., 2012), contributing higher panicle length observed. 
Planting methods significantly influenced the test weight of rice. Mean values were high for test weight in SRI (22.5, 22.7 and 22.6g in 2015, 2016 and in pooled means, respectively) as compared to NTP (20.7, 21.2 and 20.9 $\mathrm{g}$ in 2015, 2016 and in pooled means, respectively). This might be due to, alternate wetting and moderate soil drying with wider spacing, which possibly improved the root growth with open canopy structure. These conditions perhaps delayed leaf senescence while facilitating greater light utilization for higher photosynthetic rates during reproductive and grain filling stages. In SRI these features might also contribute to the improvement of grain filling and grain weight in SRI grown plants (Thakur et al., 2011). Significant variation was observed in test weight due to the nitrogen treatments.

The higher average value of test weight was found in $\mathrm{N}_{5}$ (23.4 and 23.3g during 2015 and 2016 , respectively) followed by $\mathrm{N}_{6}, \mathrm{~N}_{2}, \mathrm{~N}_{4}$ and $\mathrm{N}_{3}$. The minimum test weight was recorded in $\mathrm{N}_{1}$ (17.6 and 19.0g during 2015 and 2016, respectively). Higher test weight in $\mathrm{N}_{5}$ treatment was recorded in present investigation might be due to availability of nitrogen in two forms with $36 \%$ nitrate nitrogen and $64 \%$ in ammonical nitrogen in $\mathrm{N}_{5}$ nitrogen treatment. Similar results were also supported by Kronzucker et al., (1999).

Percentage of grain filling recorded differed significantly between NTP and SRI during both the years of study. Higher percentage of grain filling was recorded in SRI (89 and 90.0 $\%$ ) compared to NTP during 2015 and 2016, respectively (Table 2). This was because of longer panicle length and higher biomass production in SRI as supported by more leaf area, which was a major source of carbohydrate production. This positively improved the grain filling percentage in SRI. These results could be substantiated by the findings of Thakur et al., (2013). Application of nitrogen through $\mathrm{N}_{5}$ treatment recorded significantly higher percentage of grain filling over other nitrogen treatments during both the years of study. In $\mathrm{N}_{5}$ percentage of grain filling was significantly maximum as 90.3 and 90.5\% during 2015 and 2016, respectively, compared to $\mathrm{N}_{6}, \mathrm{~N}_{2}, \mathrm{~N}_{4}$ and $\mathrm{N}_{3}$ treatments.

Supply of nitrogen through splits application to the crop, which might have available nitrogen to the crop, thus provided better nitrogen uptake and lead to greater dry matter production and its translocation to sink. Similar observations were also reported by (Sathiya and Ramesh, 2009 and Singh et al., 2015). The lowest percentage of grain filling was observed in $\mathrm{N}_{1}$ (80.6, 80.4 and 80.5 during 2015, 2016 and in pooled means, respectively).

The NTP registered significantly higher percentage of spikelet sterility (15.4 and $16.0 \%)$ as compared to SRI (11.0 and 10.1\%) during 2015 and 2016, respectively. The possible reason could be lack of sufficient photosynthates and higher inter and intra tiller competition with closer spacing during dry matter partitioning under NTP. These results have been supported by the findings of Rajendran et al., (2013). Application of nitrogen through $\mathrm{N}_{5}$ recorded significantly lower percentage of spikelet sterility (9.7 and $9.5 \%$ ) which was significantly different with other nitrogen treatments. The $\mathrm{N}_{1}$ treatment registered higher percentage of spikelet sterility (19.4 and 19.6 \%) during 2015, 2016 and in pooled means, respectively. Application and combination of organic manures sustained the plants green even at the time of maturity. Hence, the contribution of carbohydrates from current photosynthetic activity and the efficient translocation into the grain has resulted in increased number of filled grains and reduced the unfilled grains panicle $^{-1}$. These results were in agreement with the Wijebandara et al., (2009). 
Table.1 Panicle length $(\mathrm{cm})$ and test weight $(\mathrm{g})$ influenced by Planting methods and nitrogen treatments in Rice

\begin{tabular}{|l|c|c|c|c|c|c|}
\hline \multirow{2}{*}{ Treatments } & \multicolumn{3}{|c|}{ Panicle length (cm) } & \multicolumn{3}{c|}{ Test weight (g) } \\
\cline { 2 - 7 } & $\mathbf{2 0 1 5}$ & $\mathbf{2 0 1 6}$ & Pooled & $\mathbf{2 0 1 5}$ & $\mathbf{2 0 1 6}$ & Pooled \\
\hline Mean values of main treatments (M) & \multicolumn{5}{|c|}{} \\
\hline M1- System of Rice Intensification (SRI) & 24.4 & 24.4 & 24.4 & 22.5 & 22.7 & 22.6 \\
\hline M2-Normal Transplantation (NTP) & 23.0 & 23.2 & 23.1 & 20.7 & 21.2 & 20.9 \\
\hline S.Em \pm & 0.52 & 0.1 & 0.29 & 0.03 & 0.14 & 0.06 \\
\hline C.D. at 5\% & N S & 0.6 & 1.8 & 0.19 & 0.86 & 0.34 \\
\hline Mean values of sub treatments (N) & \multicolumn{5}{|l|}{} \\
\hline N1 - Control & 22.1 & 22.2 & 22.2 & 17.6 & 19 & 18.3 \\
\hline N2 - 100\% Organic & 23.9 & 23.9 & 23.9 & 22.3 & 22.5 & 22.4 \\
\hline N3 - 75 \% organic + 25\% inorganic & 23.6 & 23.8 & 23.7 & 20.6 & 21.9 & 21.3 \\
\hline N4 - 50\% organic + 50\% inorganic & 23.8 & 23.9 & 23.9 & 22.9 & 22.2 & 22.5 \\
\hline N5 - 25 \% organic + 75\% inorganic & 24.6 & 24.7 & 24.7 & 23.4 & 23.3 & 23.4 \\
\hline N6 - 100\% inorganic & 24.2 & 24.2 & 24.2 & 22.8 & 22.8 & 22.8 \\
\hline S.Em \pm & 0.5 & 0.49 & 0.44 & 0.48 & 0.47 & 0.33 \\
\hline C.D. at 5\% & 1.47 & 1.45 & 1.17 & 1.42 & 1.4 & 0.96 \\
\hline TXM & N S & N S & N S & N S & N S & N S \\
\hline MXT & N S & N S & N S & N S & N S & N S \\
\hline
\end{tabular}

Table.2 Grain filling (\%) and Spikelet sterility (\%) influenced by Planting methods and nitrogen treatments in Rice

\begin{tabular}{|c|c|c|c|c|c|c|}
\hline \multirow{2}{*}{ Treatments } & \multicolumn{3}{|c|}{ Grain filling (\%) } & \multicolumn{3}{|c|}{ Spikelet sterility (\%) } \\
\hline & 2015 & 2016 & Pooled & 2015 & 2016 & Pooled \\
\hline \multicolumn{7}{|l|}{ Mean values of main treatments $(\mathrm{M})$} \\
\hline M1- System of Rice Intensification (SRI) & 89.0 & 90.0 & 89.5 & 11.0 & 10.1 & 10.5 \\
\hline M2-Normal Transplantation (NTP) & 84.7 & 84.0 & 84.3 & 15.4 & 16.0 & 15.7 \\
\hline S.Em \pm & 0.4 & 0.5 & 0.3 & 0.4 & 0.5 & 0.3 \\
\hline C.D. at $5 \%$ & 2.2 & 2.8 & 1.7 & 2.2 & 2.8 & 1.7 \\
\hline \multicolumn{7}{|l|}{ Mean values of sub treatments $(\mathrm{N})$} \\
\hline N1 - Control & 80.6 & 80.4 & 80.5 & 19.4 & 19.6 & 19.5 \\
\hline N2 - $100 \%$ Organic & 87.7 & 88.5 & 88.1 & 12.3 & 11.5 & 11.9 \\
\hline N3 - $75 \%$ organic $+25 \%$ inorganic & 86.3 & 85.5 & 85.9 & 13.7 & 14.5 & 14.1 \\
\hline $\mathrm{N} 4-50 \%$ organic $+\mathbf{5 0 \%}$ inorganic & 87.3 & 87.2 & 87.2 & 12.8 & 12.8 & 12.8 \\
\hline N5 - $25 \%$ organic $+75 \%$ inorganic & 90.3 & 90.5 & 90.4 & 9.7 & 9.5 & 9.6 \\
\hline N6 - $100 \%$ inorganic & 88.8 & 89.6 & 89.2 & 11.2 & 10.4 & 10.8 \\
\hline S.Em \pm & 0.4 & 0.4 & 0.3 & 0.4 & 0.4 & 0.3 \\
\hline C.D. at 5\% & 1.1 & 1.3 & 0.8 & 1.1 & 1.3 & 0.8 \\
\hline TXM & $\mathrm{NS}$ & $\mathrm{NS}$ & $\mathrm{NS}$ & N S & $\mathrm{N} \mathrm{S}$ & $\mathrm{NS}$ \\
\hline MXT & $\mathrm{NS}$ & $\mathrm{NS}$ & $\mathrm{N} \mathrm{S}$ & $\mathrm{NS}$ & $\mathrm{NS}$ & $\mathrm{NS}$ \\
\hline
\end{tabular}


Table.3 Grain yield, straw yield and harvest index (\%) influenced by Planting methods and nitrogen treatments in rice

\begin{tabular}{|c|c|c|c|c|c|c|c|c|c|}
\hline \multirow{2}{*}{ Treatments } & \multicolumn{3}{|c|}{ Grain yield (Kg ha $\left.{ }^{-1}\right)$} & \multicolumn{3}{|c|}{ Straw yield $\left(\mathrm{Kg} \mathrm{ha}^{-1}\right)$} & \multicolumn{3}{|c|}{ Harvest index (\%) } \\
\hline & 2015 & 2016 & Pooled & 2015 & 2016 & Pooled & 2015 & 2016 & Pooled \\
\hline \multicolumn{10}{|c|}{ Mean values of main treatments (M) } \\
\hline $\mathbf{M}_{1}$ & 6384 & 6442 & 6413 & 7495 & 7180 & 7338 & 46 & 47 & 47 \\
\hline $\mathbf{M}_{2}$ & 5413 & 5424 & 5418 & 6830 & 6505 & 6668 & 44 & 45 & 45 \\
\hline S.Em \pm & 88.99 & 130.42 & 70 & 104.81 & 51.83 & 77.67 & 0.53 & 0.42 & 0.14 \\
\hline C.D.5\% & 541.48 & 793.61 & 425.94 & 637.77 & 315.39 & 472.62 & $\mathrm{NS}$ & $\mathrm{NS}$ & 0.86 \\
\hline \multicolumn{10}{|c|}{ Mean values of sub treatments $(\mathrm{N})$} \\
\hline $\mathbf{N}_{1}$ & 4832 & 4812 & 4822 & 6570 & 6084 & 6327 & 42 & 44 & 43 \\
\hline $\mathbf{N}_{2}$ & 6053 & 6208 & 6131 & 7210 & 6969 & 7089 & 46 & 47 & 46 \\
\hline $\mathbf{N}_{3}$ & 5740 & 5578 & 5659 & 7100 & 6787 & 6944 & 45 & 45 & 45 \\
\hline $\mathbf{N}_{4}$ & 5900 & 5820 & 5860 & 7184 & 6884 & 7034 & 45 & 46 & 45 \\
\hline $\mathbf{N}_{5}$ & 6527 & 6762 & 6644 & 7565 & 7255 & 7410 & 46 & 48 & 47 \\
\hline $\mathbf{N}_{6}$ & 6338 & 6417 & 6378 & 7346 & 7078 & 7212 & 46 & 47 & 47 \\
\hline S.Em \pm & 189.82 & 307.04 & 179.83 & 180.61 & 114.83 & 107.89 & 1.03 & 1.23 & 0.6 \\
\hline C.D.5\% & 559.97 & 905.77 & 530.5 & 532.79 & 338.74 & 318.27 & $\mathrm{NS}$ & $\mathrm{NS}$ & 1.77 \\
\hline $\mathbf{T x M}$ & N S & $\mathrm{N} \mathrm{S}$ & NS & N S & $\mathrm{N} \mathrm{S}$ & N S & $\mathrm{NS}$ & $\mathrm{NS}$ & $\mathrm{NS}$ \\
\hline TxM & $\mathrm{NS}$ & $\mathrm{NS}$ & NS & $\mathrm{NS}$ & $\mathrm{NS}$ & $\mathrm{NS}$ & $\mathrm{NS}$ & $\mathrm{NS}$ & $\mathrm{NS}$ \\
\hline
\end{tabular}

Fig.1 Grain yield, straw yield and harvest index (\%) influenced by Planting methods and nitrogen treatments in rice

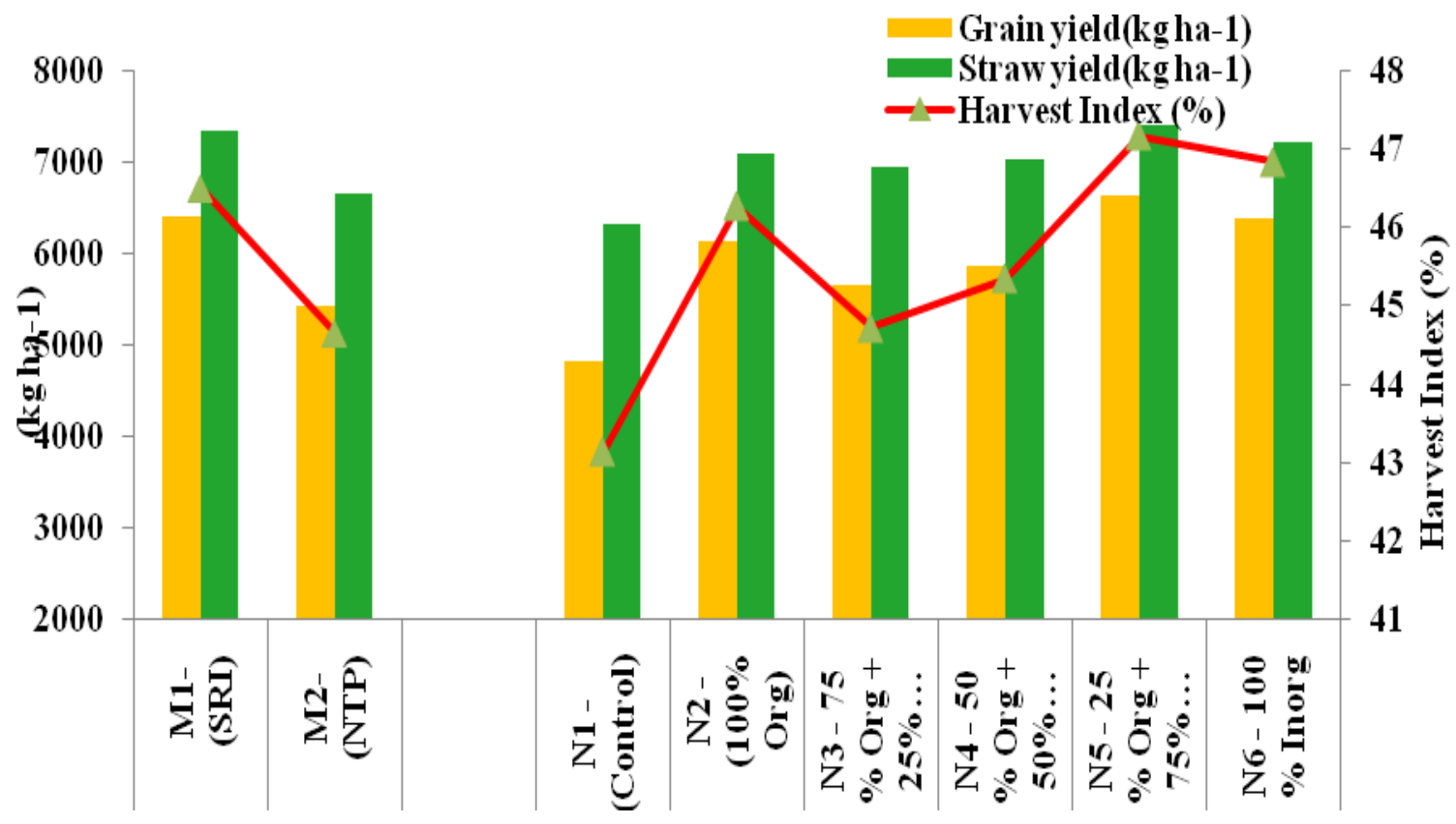


The per cent grain yield increase in SRI was 17.93, 18.77 and $18.33 \%$ over NTP during 2015, 2016 and their pooled means, respectively (Table 3). System of rice intensification planting method provides better aeration, wider spacing and less competition, which enabled the plants to grow vigorously. The increased seed yield under SRI could be attributed to the higher root growth which enabled them to access nutrients from much greater volume of soil, capturing all the essential nutrient elements important for plant growth and there by leading to higher tillering and dry matter production as has been reported earlier (Thiyagarajan et al., 2002).

The yield attributing characters such as panicle length, panicle weight, filled grains per panicle and test weight were higher in SRI method than in NTP, which was responsible for the increased grain yield (Mohanty et al., 2014). Application of nitrogen based on $25 \%$ organic $+75 \%$ inorganic $\left(\mathrm{N}_{5}\right)$ treatment was found to give significantly higher grain yield during both the years of study. The grain yield of rice in $25 \%$ organic $+75 \%$ inorganic $\left(\mathrm{N}_{5}\right)(6527,6762$ and $\left.6644 \mathrm{~kg} \mathrm{ha}^{-1}\right), 100 \%$ inorganic $\left(\mathrm{N}_{6}\right)(6338,6417$ and $\left.6378 \mathrm{~kg} \mathrm{ha}^{-1}\right)$ and $100 \%$ organic $\left(\mathrm{N}_{2}\right)(6053$, 6208 and $\left.6131 \mathrm{~kg} \mathrm{ha}^{-1}\right)$ treatments based on nitrogen management practices were statistically at par with each other but these nitrogen management practices were significantly superior over $50 \%$ organic $+50 \%$ inorganic $\left(\mathrm{N}_{4}\right)$ and $75 \%$ organic $+25 \%$ inorganic $\left(\mathrm{N}_{3}\right)$ and control $\left(\mathrm{N}_{1}\right)$ during 2015, 2016 and in pooled means, respectively.

The higher availability of nitrogen in $75 \%$ inorganic and $25 \%$ organic $\left(\mathrm{N}_{5}\right)$ treatment results in higher grain yields as higher availability of nitrogen influenced the synthesis of chlorophyll molecule, lead to proportional increases Photosynthetic rate activity and photosynthetic assimilates. These conditions improve the effective tillers, test weight of grains, filled grain percentage, and finally improve the grain yield (Thakur et al., 2013).

Straw yield of rice was significantly higher in SRI (7495 and $\left.7180 \mathrm{~kg} \mathrm{ha}^{-1}\right)$ than NTP (6830 and $6505 \mathrm{~kg} \mathrm{ha}^{-1}$ ) during 2015 and 2016, respectively. It could be because of more dry matter production per unit area caused by better nutrient absorption from soil, increased rate of metabolic processes, higher rate of light absorption and increased rate of photosynthetic activity that produced higher number of tillers and leaf area as compared to NTP planting method (Rajendran et al., (2013) and Mohanty et al., (2014)). Application of nitrogen based on $\mathrm{N}_{5}$ treatment was found to have significantly higher straw yield during both the years of study. The straw yield of rice in $\mathrm{N}_{5}$ treatment was maximum $\left(7565\right.$ and $7255 \mathrm{~kg} \mathrm{ha}^{-1}$ during 2015 and 2016, respectively) $\mathrm{N}_{6}$ and $\mathrm{N}_{2}$ treatments were statistically at par with $\mathrm{N}_{5}$ but these nitrogen treatments were significantly superior over $\mathrm{N}_{4}, \mathrm{~N}_{3}$ and $\mathrm{N}_{1}$ treatments. This might be because of adequate supply of nitrogen throughout crop growth period that led to higher dry matter production Alam et al., (2013). $\mathrm{N}_{1}$ treatment recorded lower straw yield (6570 and $6084 \mathrm{~kg} \mathrm{ha}^{-1}$ during 2015 and 2016, respectively).

The harvest index of rice was not significantly different among the planting methods and nitrogen treatments as well as interaction effect during both the years of study (Table 3). Significant difference was however observed among pooled means as observed in SRI (47\%) compared to NTP (45\%). Maximum harvest index was observed in $\mathrm{N}_{5}(47 \%)$ and lowest was recorded in $\mathrm{N}_{1}(43 \%)$. Increased harvest index in SRI system and $\mathrm{N}_{5}$ treatment might be due to highest tiller number, leaf area, total dry matter production, and grain yield and yield parameters (Fig. 1).

In conclusion, SRI compared to NTP, yield attributes like panicle length, percentage of grain filling and test weight was significantly superior. $\mathrm{N}_{5}$ treatment significantly enhanced panicle length, percentage of grain filling and test weight in the order of $N_{6}>N_{2}>N_{4}>N_{3}>N_{1}$. Grain yield was increased significantly by $18.3 \%$ under SRI over NTP. Among nitrogen treatments $\mathrm{N}_{5}$ enhanced $37.8 \%$ yield over $\mathrm{N}_{1}$ in both the years of pooled means. 


\section{References}

Choudhary, R.L., Dinesh Kumar, Shivay, Y.S., Anand, A and Lata Nain. 2013. Yield and quality of rice (Oryza sativa) hybrids grown by SRI method with and without plant growth promoting rhizobacteria. Indian Journal of Agronomy. 58 (3): 430-433.

Damodaran, V., Saren, B.K., Ravisankar, N and Bommayasamy, N. 2012. Influence of time of planting, spacing, seedling number and nitrogen management practices on productivity, profitability and energetics of rice (Oryza sativa) in island ecosystem. Madras Agricultural Journal. 99 (7-9): 538-544.

Donald, C.M., and Humblin, J. 1962. The biological yield and harvest index of cereals as agronomic and plant breeding criteria. Advance in Agronomy. 28: 361-406.

Jayanthi, T., Gali, S.K., Chimmad, V.P and Angadi, V.V. 2007. Leaf colour chart based $\mathrm{N}$ management on yield, harvest index and partial factor productivity of rainfed rice. Karnataka Journal of Agricultural Sciences. 20(2): 405-406.

Kronzucker, H.J., Siddiqi, M.Y., Glass, A.D.M. and Kirk, G.J.D. 1999. Nitrateammonium synergism in rice a subcellular flux analysis. Journal of Plant Physiology 119, 1041-1046.

Laulanié, H., 1993. Le système de riziculture intensive malgache. Tropicultura (Brussels) 11: 110-114.

Mohanty, A.K., Islam, M., Kumar, G.A.K and Kumar, A. 2014. Enhancing rice (Oryza sativa) productivity through Demonstrations of SRI method of cultivation in mid altitude region of Indo Himalayan Belt of Sikkim. Indian Research Journal of Extension Education. 14(3): 8892.

Rajendran, K., Raja, K.G and Balasubramanian,
R. 2013. Evaluation of crop establishment techniques and weed management practices under system of rice intensification. Madras Agricultural Journal. 100(7-9): 698-702.

Ramesh, S., and Chandrasekaran, B. 2007. Evaluation of crop establishment methods and nitrogen management strategies on realizing yield potential of rice hybrid ADTRH 1. Asian Journal of Plant Sciences. 6(2): 239-251.

Thakur, A.K., Rath, S and Mandal, K.G. 2013. Differential responses of system of rice intensification (SRI) and conventional flooded rice management methods to application of nitrogen fertilizer. Plant and Soil. 370: 59-71.

Thiyagarajan, T.M., Velu, V and Bindrabam, P.S. 2007. Effect of SRI practice on rice in Tamil Nadu. IRRI Report. 26.

Tuong, T.P., and Bouman, B.A.M. 2003. Rice production in water scare environments. In L. W. Kijne, R. Barker and D. Molden, eds. Water productivity in agriculture: Limits and opportunities for improvement. The Comprehensive Assessment of Water Management in Agriculture Series. Wallingfort, UK, CABI Publishing. 1: 1342.

Wijebandara, D.M.D.I., Dasog, G.S., Patil, P.L and Hebbar, M. 2009. Response of rice to nutrients and bio fertilizers under conventional and system of rice intensification methods of cultivation in Tungabhadra command of Karnataka. Karnataka Journal of Agricultural Sciences. 22(4): 741-750.

Zhang, H., Chen, T.T., Wang, Z.Q., Yang, J.C and Zhang, J.H. 2010. Involvement of cytokinin in the grain filling of rice under alternate wetting and drying irrigation. Journal of Experimental Botany. 61(13): 3719-3733.

\section{How to cite this article:}

Praneeth, S., D. Vishnu Vardhan Reddy, R. Mahender Kumar, P.C. Latha, T. Ramesh and Raguveer Rao. 2017. Yield and Yield Attributes Influenced by Different Planting Methods and Nitrogen Treatments. Int.J.Curr.Microbiol.App.Sci. 6(8): 3061-3067. doi: https://doi.org/10.20546/ijcmas.2017.608.366 